\title{
PEMBUATAN SISTEM JARINGAN INSTALASI PENGOLAHAN AIR LIMBAH LABORATORIUM LINGKUNGAN
}

\author{
HIJRIATI SHOLEHAH, ERLAN SISWANDI, AZWARUDDIN, \\ NURHIDAYATULLAH, NURHIDAYAH \\ Sekolah Tinggi Teknik Lingkungan Mataram \\ Email : hijriati.chemist@gmail.com
}

\begin{abstract}
ABSTRAK
Tujuan pengabdian untuk merancang sistem instalasi pengolahan air limbah yang akan digunakan terhadap limbah Laboratorium di lingkungan STTL Mataram. Permasalahan limbah cair dari Laboratorium di lingkungan STTL Mataram dari kondisi yang ada belum mempunyai Instalasi Pengelolaan Air Limbah (IPAL). Limbah cair dari Laboratorium masih dalam satu jaringan dengan limbah cair domestik. Sehingga perlu di buatkan IPAL khusus untuk limbah cair Laboratorium Lingkungan STTL Mataram. Sebelum membuat IPAL terlebih dahulu mengetahui kandungan dari air limbah tersebut hal ini bertujuan untuk mengetahui jenis limbah apa saja yang paling banyak terdapat pada limbah cair laboratorium sehingga dilakukan pengujian air limbah Laboratorium dengan menggunakan beberapa parameter seperti BOD, COD, TSS, pH dan Colifrom. Dalam pengujian air limbah Laboratorium STTL Mataram, bakteri Colifrom merupakan bakteri yang melebihi Nilai Ambang Batas dan instalasi pengolaahan air limbah dapat dibuat selama proses pengabdian berlangsung.
\end{abstract}

Kata Kunci: IPAL, Limbah, Bakteri

\section{ABSTRACT}

The purpose of the service is to design a wastewater treatment installation system that will be used for laboratory waste in the Mataram STTL environment. The problem of liquid waste from the laboratory in the STTL Mataram environment from the existing conditions does not yet have a Waste Water Management Installation (IPAL). Liquid waste from the laboratory is still in the same network as domestic liquid waste. So it is necessary to make a special WWTP for the liquid waste of the Mataram STTL Environmental Laboratory. Before making the WWTP first, knowing the content of the wastewater, this aims to find out what types of waste are most commonly found in laboratory liquid waste, so that laboratory wastewater testing is carried out using several parameters such as BOD, COD, TSS, $\mathrm{pH}$ and Colifrom. In testing the wastewater of the Mataram STTL Laboratory, Colifrom bacteria are bacteria that exceed the Threshold Value and wastewater treatment plants can be made during the service process.

Keywords: WWTP, Waste, Bacteria

\section{PENDAHULUAN}

Bagian pendahuluan terutama berisi: (1) analisis situasi; (2) permasalahan mitra; (3) solusi yang ditawarkan; dan (4) target luaran.

Laboratorium Lingkungan STTL Mataram telah beroperasi sejak berdirinya kampus STTL Mataram dan saat ini digunakan sebagai tempat praktikum dengan mata kuliah tertentu oleh seluruh mahasiswa STTL Mataram serta sudah menerima pengujian baik dari mahasiswa STTL Mataram ataupun dari luar. Laboratorium tersebut juga sudah dilengkapi dengan fasilitas yang memadai dan telah mendapatkan bantuan dana Hibah pada tahun 2019 untuk pengadaan alat-alat Laboratorium Lingkungan. Sehingga berbagai macam jenis kegiatan praktikum bisa dilakukan untuk menunjang kegiatan belajar mengajar. Namun, adapun permasalahan muncul yaitu terkait limbah cair yang dihasilkan.

Permasalahan limbah cair dari laboratorium di lingkungan STTL Mataram dari kondisi yang ada belum mempunyai Instalasi Pengelolaan Air Limbah (IPAL). Limbah cair dari laboratorium masih dalam satu jaringan dengan limbah cair domestik. Sehingga perlu di buatkan IPAL khusus untuk limbah cair Laboratorium Lingkungan STTL Mataram. Sebelum 
membuat IPAL terlebih dahulu mengetahui kandungan dari air limbah tersebut hal ini bertujuan untuk mengetahui jenis limbah apa saja yang paling banyak terdapat pada limbah cair laboratorium sehingga dilakukan pengujian air limbah laboratorium dengan menggunakan beberapa parameter seperti BOD, COD, TSS, pH dan Colifrom. Pengujian tersebut dilakukan untuk mengetahui sistem mana yang akan di pergunakan dalam pengolahan air limbah Laboratorium Lingkungan STTL Mataram nantinya.

Berdasarkan permasalahan mitra terkait pengolahan limbah cair dengan ini kami memberikan solusi dengan membuatkan instalasi perpipaan pengolahan air limbah laboratorium. Prosedur kerja pembuatan instalasi perpipaan pertama-tama dengan penyambungan pipa dari wastapel dengan pipa tee dan valve yang berfungsi untuk menutup dan membuka air imbah di aliran pipa, penyambungan pipa inlet laboratorium dengan langkahlangkah seperti grinda keramik dan pengeboran tembok, penanaman pipa lalu ditutup dengan diplester menggunakan pasir dan semen, selanjutnya sambung pipa dengan elbow sampai ke bak pertama dan terakhir pemasangan valve kedua di bak pertama. Pada IPAL STTL Mataram terdapat 4 bak sebagai pengolah limbah cair dari laboratorium agar kualitas air buangan setelah limbah sesuai dengan baku mutu yang diijinkan untuk dilepas ke lingkungan. Melalui kegiatan ini mitra sangat mendukung setiap kegiatan yang dilakukan. hal ini ditunjukkan dengan keterlibatan mitra dari setiap pelaksanaan kegiatan yang dilakukan. Adapun luaran yang diharapkan dari pengabdian ini adalah dapat dipublikasikan pada jurnal nasional.

\section{METODE PELAKSANAAN}

\section{Pelaksanaan kegiatan}

Lokasi kegiatan pengabdian kepada masyarakat (PKM) ini dilakukan di lingkungan STTL Mataram pada tanggal 29 Maret - 24 April 2021, dimana kegiatan ini melibatkan beberapa mahasiswa STTL Mataram.

2. Metode

a. Bahan-bahan

Bahan yang di gunakan dalam pembuatan jaringan IPAL ini adalah :

1) Pipa PVC diameter 1 inchi

2) Elbow pipa PVC diameter 1 inchi

3) Blower fan

4) Lem PVC

5) Semen $1 \mathrm{sak}(50 \mathrm{~kg})$

6) Pasir

7) Plaster

b. Alat-alat

1) Mesin bor

2) Gergaji

3) Linggis

4) Saringan pasir

5) Skop

6) Cetok semen

c. Prosedur Pembuatan

$>$ Pembuatan Instalasi Perpipaan

1. Pertama-tama dengan penyambungan pipa dari wastapel dengan pipa tee dan valve yang berfungsi untuk menutup dan membuka air imbah di aliran pipa

2. Kedua dengan penyambungan pipa inlet laboratorium dengan langkah-langkah seperti grinda keramik dan pengeboran tembok

3. Ketiga dengan penanaman pipa lalu di tutup dengan diplester menggunakan pasir dan semen

4. Selanjutnya sambung pipa dengan elbow sampai ke bak pertama

5. Trakhir pemasangan valve kedua di bak pertama 


\section{Penambahan Material dari Bak IPAL}

Pada IPAL STTL Mataram terdapat 4 bak sebagai pengolah limbah cair dari laboratorium agar kualitas air buangan setelah limbah sesuai dengan baku mutu yang diijinkan untuk dilepas ke lingkungan. Pengolahan tersebut seperti pada gambar di bawah ini :

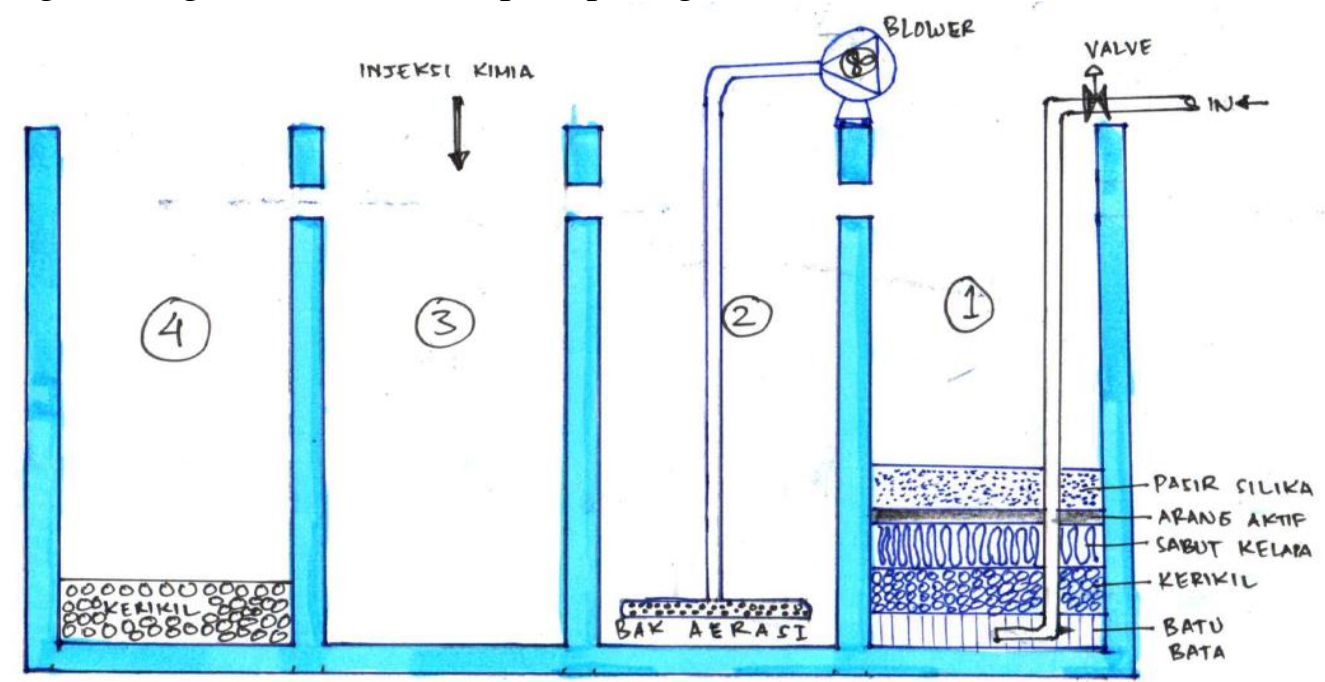

Gambar 1. Penambahan Material Bak IPAL

1. Pada bak pertama ukuran $76 \times 55 \times 100 \mathrm{~cm}$ dengan sistem pengolahan secara fisik dengan memasukkan bahan-bahan seperti batu-bata $15 \mathrm{~cm}$, krikil $20 \mathrm{~cm}$, serabut kelapa $5 \mathrm{~cm}$, arang $3 \mathrm{~cm}$, dan pasir silika $17 \mathrm{~cm}$. Ukuran bak

2. Pada bak kedua ukuran 76 × 65 x $100 \mathrm{~cm}$ dengan sistem pengolahan secara biologi dengan bantuan blower fan dan di sambungkan pipa lalu pada bagian bawah pipa di lubangi agar angin masuk dan nanti di berikan larutan EM4 untuk perkembangan bakteri yang ada pada air limbah

3. Pada bak ketiga ukuran $76 \times 60 \times 100 \mathrm{~cm}$ dengan sistem pengolahan secara kimia dengan memasukkan cairan klorin untuk mematikan bakteri yang ada pada air limbah

4. Pada bak keempat atau bak terakhir ukuran $76 \times 60 \times 100 \mathrm{~cm}$ dengan menggunakan sistem sumur resapan dengan penambahan batu bata $15 \mathrm{~cm}$, batu besar $7 \mathrm{~cm}$ dan krikil $8 \mathrm{~cm}$.

\section{HASIL DAN PEMBAHASAN}

Kegiatan pengabdian ini difokuskan di lingkungan STTL Mataram yaitu pembuatan sistem jaringan instalasi pengolahan air limbah Laboratorium Lingkungan STTL Mataram. Berdasarkan hasil pengujian air limbah laboratorium STTL Mataram diketahui bahwa parameter dari Colifrom dengan hasil perhitungan $24.000 \mathrm{jmlh} / 100 \mathrm{ml}$ telah melebihi baku mutu air limbah yang ditentukan. Sesuai dengan Permen LHK No. 68 tahun 2016 tentang baku mutu air limbah domestik Nilai Ambang Batas maksimal yang di tentukan adalah $3000 \mathrm{jmlh} / 100 \mathrm{ml}$. Maka dari itu, pembuatan Instalasi Air Limbah berfokus pada parameter Colifrom. Sitem pengolahan yang digunakan adalah dengan sistem pengolahan secara fisik, bilogi dan kimia.

\section{Realisasi Pengerjaan Sistem Jaringan IPAL}

\section{Pemasangan Instalasi Pipa}

Pada pemasangan instalasi pipa air limbah laboratorium di mulai dari saluran pipa wastapel sampai ke bak pertama pengolahan air limbah. pipa yang di pasang adalah pipa PVC diameter 1 inchi dan menghabiskan sebanyak 2 lonjor. 


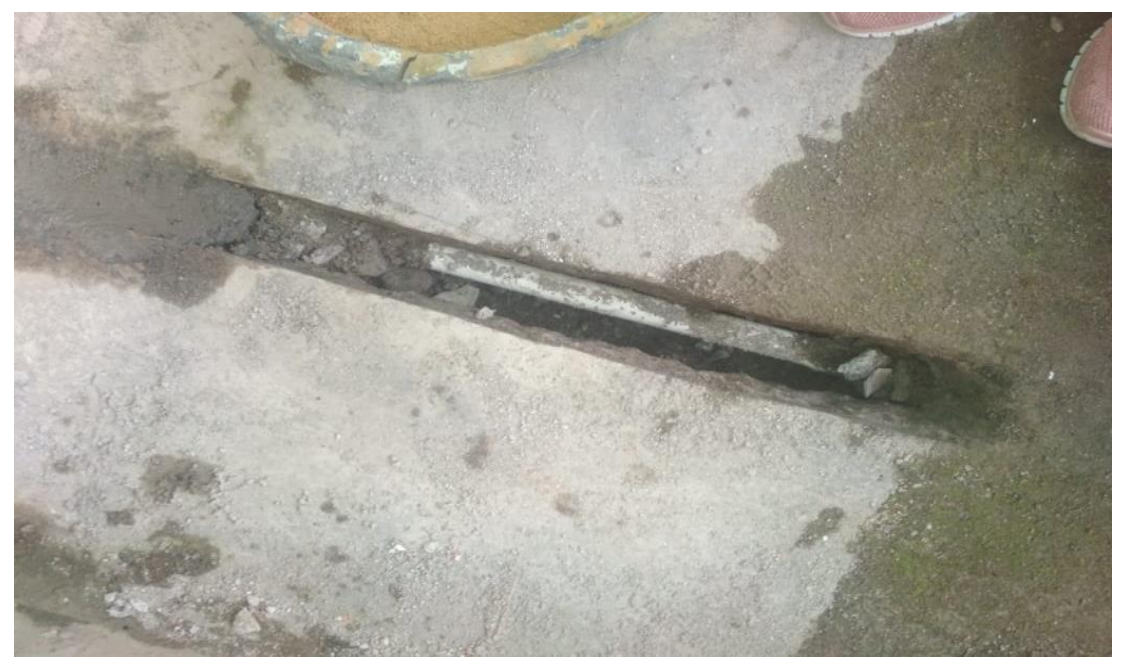

Gambar 2. Pemasangan Instalasi Pipa

\section{Pengujian Parameter Air Limbah Laboratorium}

Pengujian air limbah laboratorium dilakukan di Laboratorium STTL Mataram itu sendiri. Parameter yang di uji seperti BOD,COD,TSS,PH dan Colifrom. Hasil pengujian menunjukkan bahwa parameter Colifrom yang melebihi baku mutu yang telah ditentukan sesuai dengan Permen LHK no. 68 tahun 2016 tentang baku mutu air limbah domestik Nilai Ambang Batas maksimal yang ditentukan adalah $3000 \mathrm{jmlh} / 100 \mathrm{ml}$.

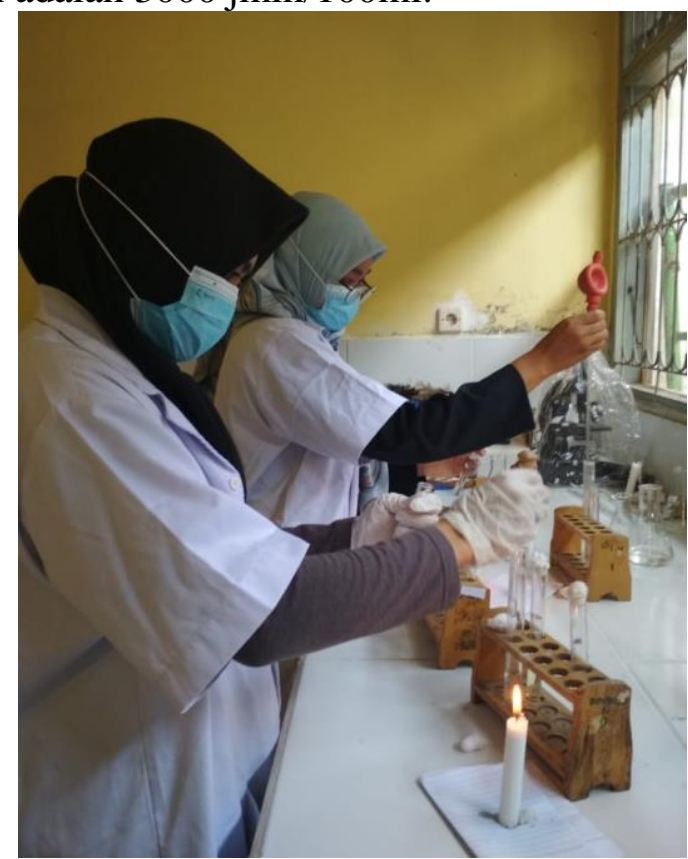

Gambar 3. Pengujian Air Limbah

\section{Penambahan Material pada Bak 1}

Pada bak pertama dengan sistem pengolahan secara fisik di tambahkan berbagai material seperti pada bagian dasar berupa batu bata, lapisan kedua batu besar, lapisan ketiga serabut kelapa, lapisan keempat arang dan lapisan paling atas pasir silika. Penambahan material tersebut berfungsi untuk mengurangi padatan, menghilangkan bau dan menyaring partikel besar maupun partake ang kecil. 


\section{Gambar 4. Penambahan Material Di Bak Ke-1}

\section{Pemasangan Blower pada Bak ke-2}

Pada bak ke-2 dengan sistem pengolahan secara Biologi di pasangkan blower dan penambahan em4 yang berfungsi untuk pertumbuhan/perkembangan bakteri yang ada di dalam bak kedua. Fungsi dari blower tersebut untuk memberikan oksigen kepada bakteri agar tetap hidup.

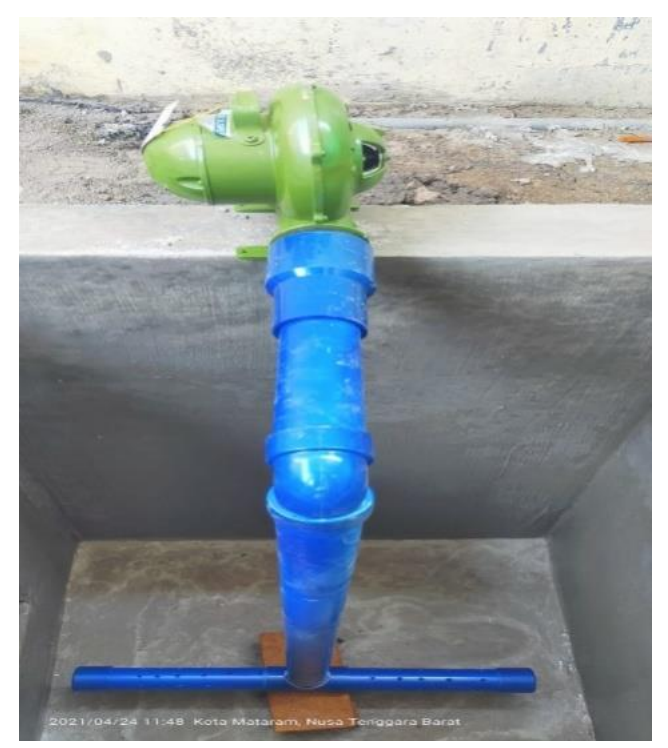

Gambar 5. Pemasangan Blower di Bak ke-2

\section{Penambahan Klorin pada Bak ke-3}

Pada bak ke-3 dengan sistem pengolahan secara kimia ditambahankan klorin pada bak ke3. Penambahan kaporit tersebut berfungsi untuk membunuh bakteri coliform yang terkandung di dalam air limbah laboratorium. 


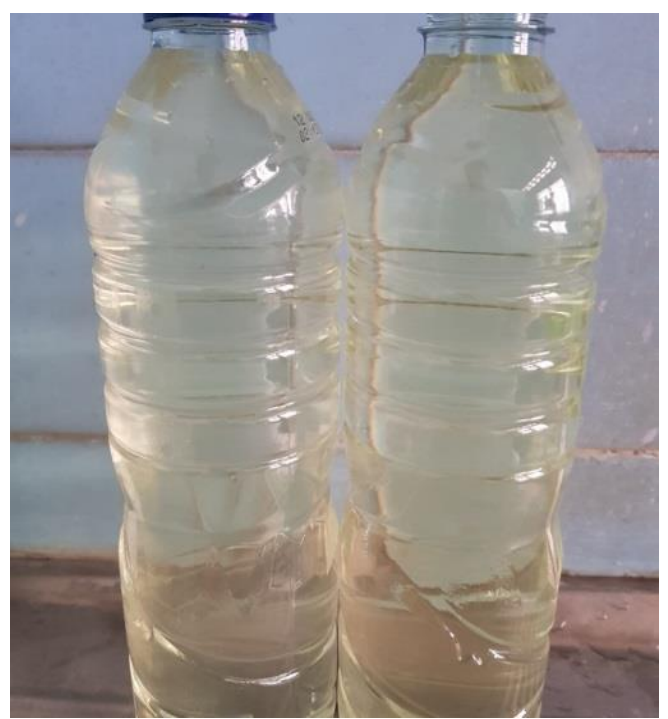

Gambar 6. Penambahan Klorin di Bak ke-3

\section{KESIMPULAN}

Pelaksanaan program pengabdian di lingkungan STTL Mataram selama 1 bulan sejak tanggal 29 Maret sampai dengan 24 April 2021. Dari kegiatan-kegiatan yang sudah dilaksanaan dapat diambil kesimpulan sebagai berikut:

1. Dalam pengujian air limbah Laboratorium STTL Mataram, bakteri Colifrom merupakan bakteri yang melebihi Nilai Ambang Batas.

2. Instalasi pengolaahan air limbah dapat dibuat selama proses pengabdian berlangsung.

\section{DAFTAR PUSTAKA}

Bilotta, G.S., R.E. Brazier. 2008. Understanding the Influence of Suspended Solids on Water Quality and Aquatic Biota. Water Research. 42. 2849-2861.

Boyd, C.E. 1990. Water Quality in Ponds for Aquaculture.Alabama Agricultural Experiment Station, Auburn University, Alabama. 482 p.

Effendi, H. 2003. Telaah Kualitas Air Bagi Pengelolaan Sumber Daya dan Lingkungan. Kanisius. Yogyakarta. 98 hal.

Mays, L.W.(Editor in Chief) 1996. Water Resources Handbook. McGraw-Hill.New York. p: 8.27-8.28.

Metcalf \& Eddy, Inc. 1991. Wastewater Engineering: Treatment, Disposal, Reuse. $3^{\text {rd }}$ ed. (Revised by: G. Tchobanoglous and F.L. Burton). McGraw-Hill,Inc. New York.

Peraturan Menteri Kesehatan RI No.416/Menkes/Per/IX/1990 tentang Syarat-Syarat dan Pengawasan Kualitas Air.

Peraturan Pemerintah Nomor 18 Tahun 1999 Tentang Pengelolaan Limbah Bahan Berbahaya dan Beracun.

Permen LHK no. 68 tahun 2016 tentang Baku Mutu Air Limbah Domestic.

Umaly, R.C. dan Ma L.A. Cuvin. 1988. Limnology: Laboratory and Field Guide,PhysicoChemical Factors, Biological Factors. National Book Store,Inc. Publishers. Metro Manila. 322 p.

Wardhany, Selvy. 2015. Analisa Bakteri Coliform pada Air Minum dengan Menggunakan Metode Most Probable Number (MPN). Fakultas Farmasi Universitas Sumatera Utara. 